\title{
Synthesis, thermoanalytical, spectroscopic study and pyrolysis of solid rare earth complexes (Eu, Gd, Tb and Dy) with $p$-aminobenzoic acid
}

\author{
J.A. Teixeira ${ }^{a}$, W.D.G. Nunes ${ }^{a}$, A.L.C.S. do Nascimento ${ }^{a}$, T.A.D. Colman ${ }^{b}$, F.J. Caires ${ }^{c}$, \\ D.A. Gálico ${ }^{\mathrm{d}}, \mathrm{M}$. Ionashiro ${ }^{\mathrm{a}, *}$ \\ a Instituto de Química, UNESP-Univ. Estadual Paulista, Araraquara, SP, 14801-970, Brazil

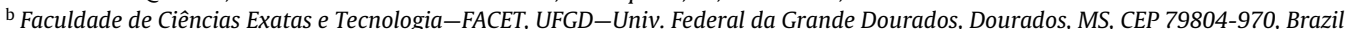 \\ ${ }^{c}$ Faculdade de Ciências-UNESP-Campus Bauru, Bauru, SP, CEP 17033-260, Brazil \\ d Instituto de Química, UNICAMP-Univ. Estadual de Campinas, Campinas, SP, 13083-970, Brazil
}

\section{A R T I C L E I N F O}

\section{Article history:}

Received 29 June 2016

Received in revised form 5 August 2016

Accepted 6 August 2016

Available online 8 August 2016

\section{Keywords:}

Rare earth complexes

Pyrolysis

Thermal behavior

Spectroscopy

Evolved gases

\begin{abstract}
A B S T R A C T
Synthesis, thermoanalytical, spectroscopic study and pyrolysis of some solid-state rare earth complexes with $p$-aminobenzoic acid (Eu, Gd, Tb and Dy) were performed. All the synthesized complexes were obtained as monohydrated state and the thermal decomposition in dynamic dry air atmosphere occurs in two, three or four steps with the formation of the respective oxides, $\mathrm{Tb}_{4} \mathrm{O}_{7}$ and $\mathrm{Ln}_{2} \mathrm{O}_{3}(\mathrm{Ln}=\mathrm{Eu}, \mathrm{Gd}$ and Dy). In dynamic dry nitrogen atmosphere, the thermal decomposition occurs in three or four consecutive and/or overlapping steps and the mass loss are still being observed up to $1000^{\circ} \mathrm{C}$. The DSC curves in nitrogen atmosphere show that all complexes presented a reversible phase transition. EGA results permitted to identify the gaseous products released during pyrolysis and thermal oxidation of the complexes. The spectroscopic study provided information about vibrational and electronic transitions of the complexes. Middle and near infrared region provided information about the vibrational modes and the ligand's denticity in these complexes. Moreover, near infrared spectra together with ultraviolet and visible spectra (diffuse reflectance) provided information regarding the $4 f-4 f$ transitions of the rare earth ions. The arithmetic difference between the diffuse reflectance spectra in the solid state of the europium(III) and gadolinium(III) complexes reveals the presence of a ligand-to-metal $\left(\mathrm{O}^{2-} \rightarrow \mathrm{Eu}^{3+}\right)$ charge transfer (LMCT) in the 305-470 $\mathrm{nm}$ range.
\end{abstract}

(C) 2016 Elsevier B.V. All rights reserved.

\section{Introduction}

The complexes of rare earth ions have aroused much interest in bioinorganic and coordination chemistry, with a variety of studies on rare earth complexes showing biological activity, cytotoxic effects and luminescent and catalytic properties [1-9].

The $p$-aminobenzoic acid (H-pABA), molecular formula $\mathrm{C}_{7} \mathrm{H}_{7} \mathrm{NO}_{2}$, is a cyclic amino acid obtained as a crystalline powder or white/white-yellowish needles, also known as vitamin Bx. Although human organism does not synthesize it, H-pABA is a component present in foods, produced by essential symbiotic bacteria, and is metabolized constantly in our bodies [10-12]. In lower concentrations is a precursor of folic acid and in high concentrations has been studied in the inhibition of various bacteria and viruses, showing anticoagulant, antioxidant and immunomod-

\footnotetext{
* Corresponding author.

E-mail address: massaoi@yahoo.com.br (M. Ionashiro).
}

ulatory properties, and is the one active ingredient in formulations against ultra-violet radiation $[10,12]$. In vivo and in vitro assays demonstrated the efficacy of H-pABA in the treatment of ocular viral herpes, efficacy primarily related by capacity of inducing of synthesis endogenous interferon in our bodies [10,12].

The interest in complexes formed between rare earth ions and $p$-aminobenzoic acid is due to the fact that $p$-aminobenzoic acid, as well as rare earth ions present biological activity. Structural investigations of H-pABA and rare earth (RE) complexes has already been described. The literature describes coordination compounds formed between $\mathrm{Eu}(\mathrm{III})$ and $\mathrm{Tb}(\mathrm{III})$ ions with aminobenzoate presented different luminescent properties due to the strong electron donor effect of the $\mathrm{NH}_{2}$ group in the ortho, meta and para positions of benzene ring [13]. A fluorescence time of $580 \mu$ s and quantum emission $0.67 \mu \mathrm{a}$. was obtained for the $\left[\mathrm{Tb}(\mathrm{pABA})_{3}\left(\mathrm{H}_{2} \mathrm{O}\right)_{2}\right] \cdot 2 \mathrm{H}_{2} \mathrm{O}$ complex [13]. Single crystals were obtained by the association of H-pABA and rare earths, except Gd(III), Nd(III) and Tm(III), forming polymeric ( $\mathrm{La}, \mathrm{Ce}, \mathrm{Pr}, \mathrm{Sm}, \mathrm{Eu}, \mathrm{Tb}, \mathrm{Dy}$ and $\mathrm{Er}$ ) and binuclear (Tb, $\mathrm{Ho}, \mathrm{Yb}, \mathrm{Lu}$ and $\mathrm{Y}$ ) structures depending on the $\mathrm{pH}$ of the prepared 
solutions [14]. Nevertheless, a systematic investigation of thermal behavior, spectroscopics and pyrolysis study of these solid rare earth complexes (Eu, Gd, Tb and Dy), which plays an important role for the possible potential applications with this ligand was not described in the literature.

In this paper, the authors report the study of thermal, spectroscopic and structural properties of rare earth $(\mathrm{Eu}, \mathrm{Gd}, \mathrm{Tb}$ and Dy) complexes with $p$-aminobenzoic acid. This study is a continuation of a previous publication [15], in which some rare earth metal complexes were also characterized.

The characterization was performed using thermoanalytical (TG-DTA, DSC, TG-DSC/FTIR), spectroscopic and complementary techniques.

\section{Experimental}

\subsection{Synthesis}

The $p$-aminobenzoic acid ( $\mathrm{H}-\mathrm{pABA}, \mathrm{C}_{7} \mathrm{H}_{7} \mathrm{NO}_{2}$ ) with $99 \%$ purity was obtained from Sigma and it was used as received.

Europium, gadolinium, terbium and dysprosium chloride solutions were prepared from the corresponding metal oxides (Sigma, $99,9 \%$, analytical grade) by treatment with concentrated hydrochloric acid, following the procedure described in the literature [16]. The rare earth carbonates were prepared by adding slowly with continuous stirring saturated sodium hydrogen carbonate solution to the corresponding metal chloride previously prepared. The resulting solution was kept in a water bath until precipitation of the metal ions and then cooled to room temperature. The precipitates were washed with distilled water until elimination of chloride ions (qualitative test with $\mathrm{AgNO}_{3} / \mathrm{HNO}_{3}$ solution for chloride ions) and maintained in aqueous suspension.

Solid compounds were obtained by mixing the corresponding metal carbonates suspension with $p$-aminobenzoic acid, in slight excess. The aqueous suspension was heated to ebullition until total neutralization of the carbonate. The solutions of the respective metal $p$-aminobenzoates were evaporated up to dryness in a water bath, washed with ethanol, heated to near ebullition and filtered to remove excess $p$-aminobenzoic acid, dried at $50^{\circ} \mathrm{C}$ in a forced circulation air over during $12 \mathrm{~h}$, and kept in a desiccator over anhydrous calcium chloride.

\subsection{Experimental equipment and conditions}

In the solid-state, rare earth ions, hydration water and stoichiometry were determined from TG curves. The metal ions were also determined by complexometry with standard EDTA solutions after igniting the compounds to the respective oxides and their dissolution in hydrochloric acid solution $[17,18]$.

Carbon, hydrogen and nitrogen contents were determined by microanalytical procedures, with a CHN Elemental Analyzer from Perkin Elmer, model 2400.

X-ray powder patterns were obtained by using a Siemens D$5000 \mathrm{X}$-Ray Diffractometer employing $\mathrm{CuK} \alpha$ radiation $(\lambda=1.541 \AA$ ) and setting of $40 \mathrm{KV}$ and $20 \mathrm{~mA}$.

Infrared spectra were obtained by using a Nicolet iS10 FTIR spectrophotometer, using ATR accessory with Ge window. The FTIR spectra were recorded with 32 scans per spectrum at resolution of $4 \mathrm{~cm}^{-1}$.

Near infrared spectra were collected using a Thermo Scientific Antaris II spectrophotometer by reflectance, within the 1000-2500 $\mathrm{nm}$ range.

Diffuse reflectance (DR) spectra were acquired using a Varian Cary 5000 spectrophotometer within the $200-1000 \mathrm{~nm}$ range with spectral resolution of $0.5 \mathrm{~nm}$.
Simultaneous TG-DTA and DSC curves were obtained with two thermal analysis systems, model SDT 2960 and Q10 respectively, both from TA Instruments. The purge gas was dry air or nitrogen, for TG-DTA, and nitrogen for DSC both at a flow rate of $100 \mathrm{~mL} \mathrm{~min}^{-1}$. A heating rate of $10^{\circ} \mathrm{C} \mathrm{min}^{-1}$ was adopted, with samples weighing about $7 \mathrm{mg}$ for TG-DTA and $2 \mathrm{mg}$ for DSC. Alumina and aluminum crucibles, the latter with perforated cover, were used for recording the TG-DTA and DSC curves, respectively.

The identification of evolved gases (EGA) in dynamic dry air and nitrogen atmospheres were carried out using a TG-DSC 1 Mettler Toledo coupled to a Nicolet FTIR spectrophotometer with gas cell and DTGS $\mathrm{KBr}$ detector. The furnace and heated gas cell $\left(250^{\circ} \mathrm{C}\right)$ were coupled through a heated $\left(225^{\circ} \mathrm{C}\right) 120 \mathrm{~cm}$ stainless steel transfer line with diameter of $3.0 \mathrm{~mm}$, both purged with dry air and nitrogen $\left(50 \mathrm{~mL} \mathrm{~min}^{-1}\right)$. The FTIR spectra were recorded with 16 scans per spectrum at a resolution of $4 \mathrm{~cm}^{-1}$.

\section{Results and discussion}

\subsection{Analytical results and characterization}

The analytical and thermoanalytical (TG) data are shown in Table 1 . These results permitted to establish the stoichiometry of the compounds, which are in agreement with the general formula $\mathrm{Ln}(\mathrm{pABA})_{3} \cdot \mathrm{H}_{2} \mathrm{O}$, where Ln represents $\mathrm{Eu}, \mathrm{Gd}, \mathrm{Tb}$ and Dy and pABA are $p$-aminobenzoate.

The X-ray diffraction powder patterns, Fig. S1 Supplementary material, show that all the synthesized complexes have a crystalline structure and evidence of isomorphous complexes.

\subsection{Thermal analysis}

The simultaneous thermogravimetry and differential thermal analysis (TG-DTA) of compounds in dynamic dry air and $\mathrm{N}_{2}$ atmospheres are shown in Fig. 1a-d and a-d* respectively. These curves show mass losses in two (air) and four (N2) steps for Tb complex; three (air) and four (N2) for Dy complex; and four (air and N2) steps for Eu and Gd complexes with or without thermal events corresponding to these losses in some cases (discussed ahead in more details).

The thermal stability of the hydrate compounds (I) and anhydrous ones (II) in air and $\mathrm{N}_{2}$ atmospheres or the final temperature of thermal decomposition (III) in air, as shown by the TG-DTA curves, depends on the nature of the metal ion and atmosphere used and they follow the order:

Air atmosphere

(I) $\mathrm{Tb}>\mathrm{Eu}>\mathrm{Dy}>\mathrm{Gd}$

(II) $\mathrm{Tb}>\mathrm{Eu}>\mathrm{Dy}>\mathrm{Gd}$

(III) Dy $>$ Gd $>$ Eu $>\mathrm{Tb}$

$\mathrm{N}_{2}$ atmosphere

(I) $\mathrm{Tb}>\mathrm{Dy}>\mathrm{Eu}=\mathrm{Gd}$

(II) $\mathrm{Gd}>\mathrm{Dy}>\mathrm{Eu}>\mathrm{Tb}$

For the Eu and Gd complexes, a great similarity is noted concerning their TG-DTA profiles in both atmospheres, so the features of each of these compounds are discussed based on this similar thermal profiles. The TG-DTA of Tb and Dy complexes are discussed separately in dynamic dry air atmosphere and together in dynamic nitrogen atmosphere. 
Table 1

Analytical and thermoanalytical (TG)* data for $\operatorname{Ln}(\mathrm{pABA})_{3}, \mathrm{Ln}=\mathrm{Eu}, \mathrm{Gd}$, Dy and $\mathrm{Tb}$

\begin{tabular}{|c|c|c|c|c|c|c|c|c|c|c|c|c|c|c|}
\hline \multirow[t]{2}{*}{ Compounds } & \multicolumn{3}{|c|}{ Ln (oxide)/\% } & \multicolumn{2}{|c|}{$\mathrm{L}$ (lost)/\% } & \multicolumn{2}{|c|}{$\mathrm{H}_{2} \mathrm{O} / \%$} & \multicolumn{2}{|l|}{$\mathrm{C} / \%$} & \multicolumn{2}{|l|}{$\mathrm{H} / \%$} & \multicolumn{2}{|l|}{$\mathrm{N} / \%$} & \multirow[t]{2}{*}{ Final Residue } \\
\hline & Calc. & EDTA & TG & Calc. & TG & Calc. & TG & Calc. & EA & Calc. & EA & Calc. & EA & \\
\hline $\mathrm{Eu}(\mathrm{pABA})_{3} \cdot \mathrm{H}_{2} \mathrm{O}$ & 30.43 & 30.56 & 30.19 & 66.46 & 66.56 & 3.12 & 3.25 & 43.60 & 43.38 & 7.26 & 7.11 & 3.49 & 3.20 & $\mathrm{Eu}_{2} \mathrm{O}_{3}$ \\
\hline $\mathrm{Gd}(\mathrm{pABA})_{3} \cdot \mathrm{H}_{2} \mathrm{O}$ & 31.05 & 30.91 & 31.16 & 65.86 & 65.62 & 3.09 & 3.22 & 43.21 & 43.21 & 7.20 & 7,01 & 3.46 & 3.25 & $\mathrm{Gd}_{2} \mathrm{O}_{3}$ \\
\hline $\mathrm{Tb}(\mathrm{pABA})_{3} \cdot \mathrm{H}_{2} \mathrm{O}$ & 31.93 & 32.04 & 32.50 & 64.99 & 64.59 & 3.08 & 2.91 & 43.09 & 42.70 & 7.19 & 6.80 & 3.45 & 3.30 & $\mathrm{~Tb}_{4} \mathrm{O}_{7}$ \\
\hline $\mathrm{Dy}(\mathrm{pABA})_{3} \cdot \mathrm{H}_{2} \mathrm{O}$ & 31.67 & 31.55 & 31.40 & 65.27 & 65.45 & 3.06 & 3.15 & 42.82 & 43.01 & 7.14 & 7.37 & 3.43 & 3.50 & $\mathrm{Dy}_{2} \mathrm{O}_{3}$ \\
\hline
\end{tabular}

TG in air atmosphere, $\mathrm{pABA}=p$-aminobenzoate.
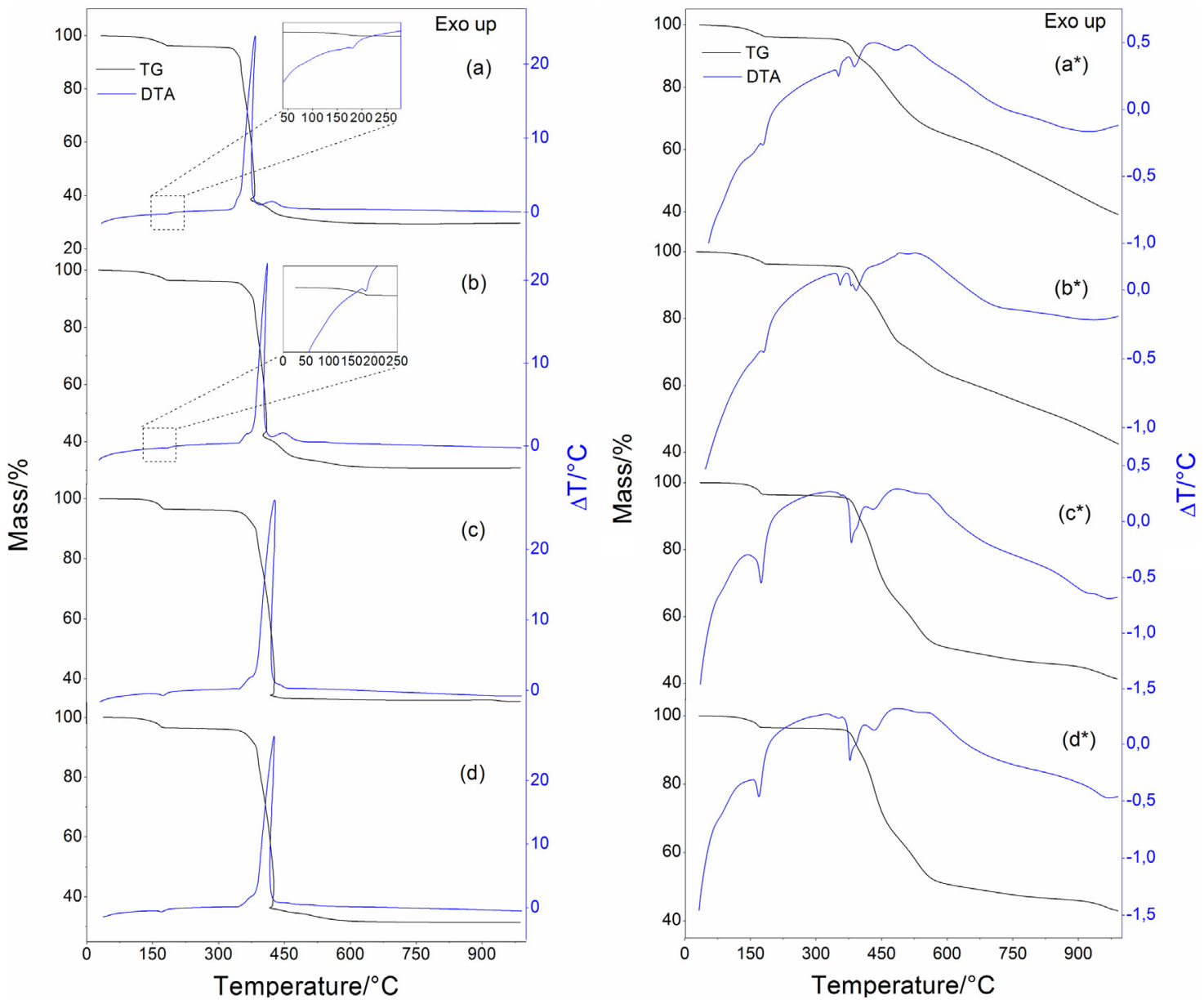

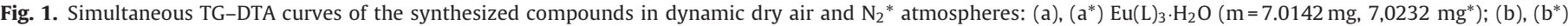
$\mathrm{Gd}(\mathrm{L})_{3} \cdot \mathrm{H}_{2} \mathrm{O}\left(\mathrm{m}=7.0156 \mathrm{mg}, 7,0310 \mathrm{mg}^{*}\right) ;(\mathrm{c}),\left(\mathrm{c}^{*}\right) \mathrm{Tb}(\mathrm{L})_{3} \cdot \mathrm{H}_{2} \mathrm{O}\left(\mathrm{m}=7.0178 \mathrm{mg}, 7 ; 0223 \mathrm{mg}^{*}\right) ; \mathrm{Dy}(\mathrm{L})_{3} \cdot \mathrm{H}_{2} \mathrm{O}(\mathrm{m}=7.0108 \mathrm{mg}, \mathrm{m}=7.0112 \mathrm{mg} *)$.

3.2.1.1.1. Europium and Gadolinium complexes. The simultaneous TG-DTA curves of europium and gadolinium complexes in dynamic dry air atmosphere are shown in Fig. 1a and b, respectively. The first mass loss between $110-190 \mathrm{C}(\mathrm{Eu})$ and $105-190^{\circ} \mathrm{C}$ $(\mathrm{Gd})$, corresponding to an indicium of endothermic event at $185^{\circ} \mathrm{C}$ (Eu and $\mathrm{Gd}$ ) is attributed to dehydration with loss of $1 \mathrm{H}_{2} \mathrm{O}(\mathrm{Eu}, \mathrm{Gd}$, Calcd. $=3.12 \%, 3.09 \%$; $\mathrm{TG}=3.25 \%, 3.22 \%$ ).

The anhydrous complexes are stable up to $320^{\circ} \mathrm{C}(\mathrm{Eu})$ and $340^{\circ} \mathrm{C}(\mathrm{Gd})$ and above this temperature the mass losses occur in three consecutives steps between 320 and $380^{\circ} \mathrm{C}, 380-440{ }^{\circ} \mathrm{C}$ and $440-630^{\circ} \mathrm{C}(\mathrm{Eu})$ or $340-415^{\circ} \mathrm{C}, 415-480^{\circ} \mathrm{C}$ and $480-630^{\circ} \mathrm{C}(\mathrm{Gd})$ with losses of $58.20 \%, 5.23 \%$ and $3.13 \%$ (Eu) or $54.90 \%, 7.15 \%$ and $3.57 \%(\mathrm{Gd})$, respectively. In correspondence with the mass losses of TG curves the DTA ones show a large and sharp exothermic peak at $380^{\circ} \mathrm{C}(\mathrm{Eu})$ and $415^{\circ} \mathrm{C}(\mathrm{Gd})$, attributed to thermal oxidation of the organic matter and/or of the gaseous products evolved during the thermal oxidation and oxidation of the organic matter with the formation of a mixture of carbonaceous residue and a derivative of carbonate, respectively. The formation of this mixture in the thermal oxidation process was confirmed by test with hydrochloric acid solution on sample heated up to $440^{\circ} \mathrm{C}(\mathrm{Eu})$ and $480^{\circ} \mathrm{C}(\mathrm{Gd})$ as indicated by the TG-DTA curves, where evolution of $\mathrm{CO}_{2}$ and presence of carbonaceous residue were observed.

In both complexes the TG-DTA profiles, corresponding to the first mass loss of the anhydrous compound, show that the oxidation of organic matter and/or of the gaseous products evolved during the thermal oxidation occurs with combustion.

The last step between 440 and $630^{\circ} \mathrm{C}(\mathrm{Eu})$ and $480-630^{\circ} \mathrm{C}(\mathrm{Gd})$ with loss of $3.14 \%$ and $3.57 \%$, respectively without thermal event is attributed to the oxidation of the carbonaceous residue together with the thermal decomposition of the derivative of carbonate. No thermal event corresponding to the last step is observed, probably because the energy balance between oxidation of the carbonaceous 
residue (exo) and thermal decomposition of derivative of carbonate (endo) is not sufficient to produce a thermal event.

The total mass loss up to $630^{\circ} \mathrm{C}$ (Eu and $\mathrm{Gd}$ ) is agreement with the formation of europium and gadolinium oxides $\left(\mathrm{Eu}_{2} \mathrm{O}_{3}\right.$ and $\mathrm{Gd}_{2} \mathrm{O}_{3}$ ), as final residue (Calcd. $=69.57 \%, 68.95 \%$; $\mathrm{TG}=68.81 \%$, $68.84 \%$, respectively.)

3.2.1.1.2. Terbium complex. The simultaneous TG-DTA curves of the complex are shown in Fig. 1c. The first mass loss between 120 and $180^{\circ} \mathrm{C}$, corresponding to an endothermic peak at $175^{\circ} \mathrm{C}$ is attributed to dehydration whit loss of $1 \mathrm{H}_{2} \mathrm{O}$ (Calcd. $=3.08 \%$, TG $=2.91 \%$ ).

The anhydrous compound is stable up to $345^{\circ} \mathrm{C}$ and above this temperature the thermal decomposition occurs in a single step between 345 and $450{ }^{\circ} \mathrm{C}$ with loss of $64.59 \%$, corresponding to a sharp exothermic peak at $430^{\circ} \mathrm{C}$, attributed to the oxidation of the organic matter and/or of the gaseous products evolved during the thermal decomposition together with the oxidation of $\mathrm{Tb}$ (III) to $\mathrm{Tb}_{4} \mathrm{O}_{7}$. The total mass loss up to $450^{\circ} \mathrm{C}$ is in agreement with the formation of $\mathrm{Tb}_{4} \mathrm{O}_{7}$, as final residue (Calcd. $=68.07 \%, \mathrm{TG}=67.50 \%$ ). As already observed in TG curve of Eu and Gd compounds, the discontinuity in the final of the TG curves also shows that the thermal decomposition occurs with combustion.

3.2.1.1.3. Dysprosium complex. The simultaneous TG-DTA curves of the dysprosium complex are shown in Fig. 1d. The first mas loss between 95 and $175^{\circ} \mathrm{C}$, corresponding to endothermic peak at $170^{\circ} \mathrm{C}$ is attributed to dehydration with loss of $1 \mathrm{H}_{2} \mathrm{O}$ (Calcd. $=3.06 \%$, TG $=3.15 \%$ ).

The anhydrous complex is stable up to $340^{\circ} \mathrm{C}$ and above this temperature, the mass loss occurs in two consecutive steps. The first step that occurs through a fast process between 340 and $430^{\circ} \mathrm{C}$, with loss of $60.60 \%$ corresponding to a sharp exothermic peak at $430^{\circ} \mathrm{C}$, is attributed to oxidation of the organic matter and/or of the gaseous products evolved during the thermal decomposition, with the formation of carbonaceous residue and a derivative of carbonate. Test with hydrochloric acid solution on sample heated up to the temperature of formation of this intermediate, as indicated by the corresponding TG-DTA curves, confirmed evolution of $\mathrm{CO}_{2}$ and presence of carbonaceous residue.

The last step that occurs slowly between 430 and $660^{\circ} \mathrm{C}$, with loss of $4.85 \%$, is attributed to oxidation of carbonaceous residue (exo) and thermal decomposition of derivative of carbonate (endo). No thermal event is observed in this step because the generated heat is not sufficient to produce a thermal event. The total mass loss up to the minimum oxide level temperature is in agreement with the formation of $\mathrm{Dy}_{2} \mathrm{O}_{3}$ (Calcd. $=68.33 \%, \mathrm{TG}=68.60 \%$ ). The discontinuity observed in the final of this mass loss event shows that the thermal decomposition occurs with combustion.

\subsubsection{TG-DTA in $\mathrm{N}_{2}$ atmospheres}

3.2.2.1. Europium and Gadolinium complexes. The simultaneous TG-DTA curves of europium and gadolinium complexes in dynamic dry $\mathrm{N}_{2}$ atmosphere are shown in Fig. $1 a^{*}$ and $b^{*}$, respectively. The first mass loss between 70 and $190^{\circ} \mathrm{C}$ (Eu and Gd), corresponding to small endothermic peak at $180^{\circ} \mathrm{C}(\mathrm{Eu})$ and $185^{\circ} \mathrm{C}(\mathrm{Gd})$ is attributed to dehydration with loss of $1 \mathrm{H}_{2} \mathrm{O}$ ( $\mathrm{TG}=3.20 \%$ for both compounds, Calcd. $=3.12 \%(\mathrm{Eu}), 3.09 \% \mathrm{Gd})$.

The anhydrous complex is stable up to $348^{\circ} \mathrm{C}$ (Eu) and $360^{\circ} \mathrm{C}(\mathrm{Gd})$ and above this temperature the mass losses occur in three consecutive steps between 345 and $410^{\circ} \mathrm{C}, 410-570^{\circ} \mathrm{C}$ and $570 \rightarrow 1000^{\circ} \mathrm{C}(\mathrm{Eu})$; or $360-410^{\circ} \mathrm{C}, 410-495^{\circ} \mathrm{Cand} 495 \rightarrow 1000^{\circ} \mathrm{C}$ (Gd), with losses of $7.03 \%, 23.25 \%$ and $27.30 \%$ (Eu) or $7.06 \%, 17.38 \%$ and $29.87 \%(\mathrm{Gd})$, with the first two (Eu and $\mathrm{Gd}$ ) corresponding to endothermic peaks at $390^{\circ} \mathrm{C}$ and $490^{\circ} \mathrm{C}(\mathrm{Eu}), 380^{\circ} \mathrm{C}$ and $395^{\circ} \mathrm{C}(\mathrm{Gd})$ that were attributed to pyrolysis the compound. In the last mass loss the pyrolysis process occurs slowly and is still being observed up to $1000^{\circ} \mathrm{C}$, with indicium of a broad endothermic event that is attributed to the thermal decomposition of the carbonaceous residue.

The endothermic peak at $350^{\circ} \mathrm{C}(\mathrm{Eu})$ in the begin of the mass losses of the TG curve and $355^{\circ} \mathrm{C}(\mathrm{Gd})$, without mass loss in the TG curve is attributed to the reversible phase transition, and this was confirmed by X-ray diffractometry and DSC-photovisual heating and cooling curves, as shown in Figs. S2 and S3, respectively (Supplementary material). The imagens micrographs obtained in the DSC-photovisual system showed no visual evidence related to decomposition, oxidation and/or melting of the sample, only a slight color change was observed, characteristic of a phase transition (see video in Supplementary data).

3.2.2.2. Terbium and Dysprosium complexes. The first mass loss observed in the simultaneous TG-DTA curves of these complexes occurs between 110 and $180^{\circ} \mathrm{C}(\mathrm{Tb})$ and $85-180^{\circ} \mathrm{C}$ corresponding to an endothermic peak at $175^{\circ} \mathrm{C}$ is attributed to dehydration with loss of $1 \mathrm{H}_{2} \mathrm{O}$ in both complexes (Calcd.: $3.08 \%$, 3.06\%; TG: $3.16 \%$, $3.21 \%$, respectively), see Fig. $1 c^{*}$ and $d$.

The anhydrous compound is stable up to $340^{\circ} \mathrm{C}$ and $350^{\circ} \mathrm{C}$, respectively, and above this temperature, the mass losses occur in three consecutive steps, being the first two overlapping ones. The first two mass losses, observed between 340 and $480^{\circ} \mathrm{C}$ and $480-590{ }^{\circ} \mathrm{C}(\mathrm{Tb}), 350-475^{\circ} \mathrm{C}$ and $475-574{ }^{\circ} \mathrm{C}$ (Dy), with loss of $30.68 \%$ and $14.94 \%, 28.01 \%$ and $17.40 \%$, respectively, with endothermic peaks at $385^{\circ} \mathrm{C}$ and $435^{\circ} \mathrm{C}, 380$ and $435^{\circ} \mathrm{C}$ (Dy) is attributed to pyrolysis of the complexes, with the formation of carbonaceous residue and a derivative of carbonate.

The last step that occurs slowly, with loss of $9.87 \%$ (Tb) and $8.40 \%$ (Dy), with indicium or without endothermic event is attributed to pyrolysis of carbonaceous residue and of derivative of carbonate. For both complexes, the mass loss is still being observed up to $1000^{\circ} \mathrm{C}$.

The endothermic peak at $350^{\circ} \mathrm{C}$ (Dy) without mass loss and $360^{\circ} \mathrm{C}(\mathrm{Tb})$ in the beginning of the mass loss is attributed to reversible phase transformation, also confirmed by X-ray diffractometry and the DSC-photovisual heating and cooling curves. The X-ray diffraction powder pattern and DSC heating and cooling curves for the gadolinium complex are representative of all the compounds (see Fig. 2 and video in Supplementary material).

\subsubsection{DSC}

The DSC curves in nitrogen atmosphere of the rare earth complexes studied in this work are shown in Fig. 2.

These curves show endothermic peaks in agreement with the thermal events observed in the DTA curves up to $360^{\circ} \mathrm{C}$. The endothermic peaks at $180^{\circ} \mathrm{C}(\mathrm{Eu}), 186^{\circ} \mathrm{C}(\mathrm{Gd}), 175^{\circ} \mathrm{C}(\mathrm{Tb})$ and 170 (Dy) are attributed to dehydration. The difference observed in the peak temperature of dehydration in the DTA and DSC curves, undoubtedly is due to the experimental conditions, which were not the same. The dehydration enthalpies found for the compounds were: $75.1(\mathrm{Eu}), 76.6(\mathrm{Gd}), 68.6(\mathrm{~Tb})$ and $68.2(\mathrm{Dy}) \mathrm{kJ} \mathrm{mol}^{-1}$. The endothermic peak at $351^{\circ} \mathrm{C}(\mathrm{Eu}), 356^{\circ} \mathrm{C}(\mathrm{Gd}), 356^{\circ} \mathrm{C}(\mathrm{Tb})$ and $354^{\circ} \mathrm{C}$ (Dy) is attributed to reversible phase transformation and the measured enthalpies was: 2.9, 14.7, 4,1 and $6.9 \mathrm{~kJ} \mathrm{~mol}^{-1}$, respectively.

\subsubsection{EGA (TG-FTIR)}

The MIR spectra of the gases evolved during decomposition of terbium complex are shown as representative of the gases evolved during decomposition of all the complexes under dry air and nitrogen atmospheres in Fig. $3 a$ (air) and $b\left(\mathrm{~N}_{2}\right)$, respectively.

The EGA (TG-FTIR) spectra of the synthesized complexes obtained in dynamic dry air atmosphere shows the evolution of gases in three main steps. In the first step $\left(160^{\circ} \mathrm{C}\right)$ was observed the release of $\mathrm{H}_{2} \mathrm{O}$ associated with the dehydration step, characterized by the presence of bands between 3985 and $3352 \mathrm{~cm}^{-1}$ 


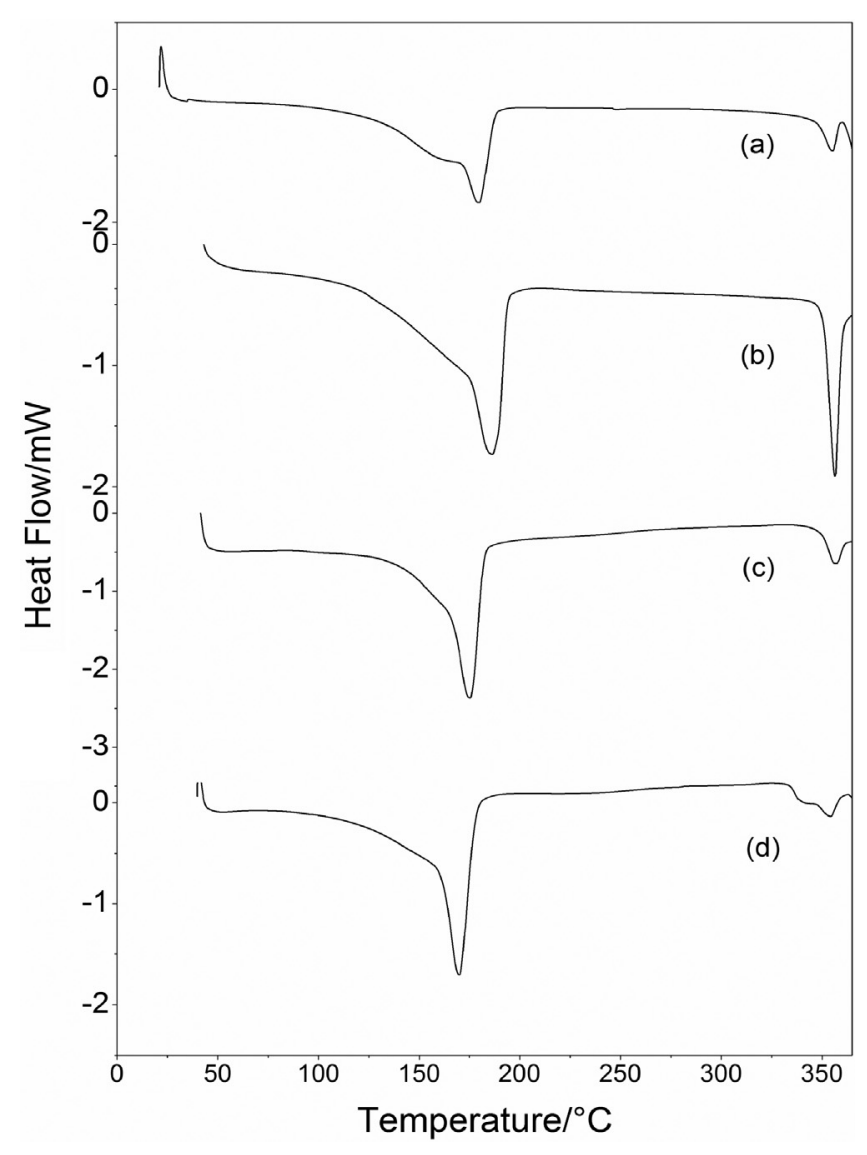

Fig. 2. DSC curves of the (a) $\mathrm{Eu}(\mathrm{L})_{3} \cdot \mathrm{H}_{2} \mathrm{O}$ ( $\mathrm{m}=2.0900 \mathrm{mg}$ ); (b) $\mathrm{Gd}(\mathrm{L})_{3} \cdot \mathrm{H}_{2} \mathrm{O}$ $(\mathrm{m}=2.0100 \mathrm{mg})$; (c) $\mathrm{Tb}(\mathrm{L})_{3} \cdot \mathrm{H}_{2} \mathrm{O}(\mathrm{m}=2.0030 \mathrm{mg})$; (d) $\mathrm{Dy}(\mathrm{L})_{3} \cdot \mathrm{H}_{2} \mathrm{O}(\mathrm{m}=1.990 \mathrm{mg})$.

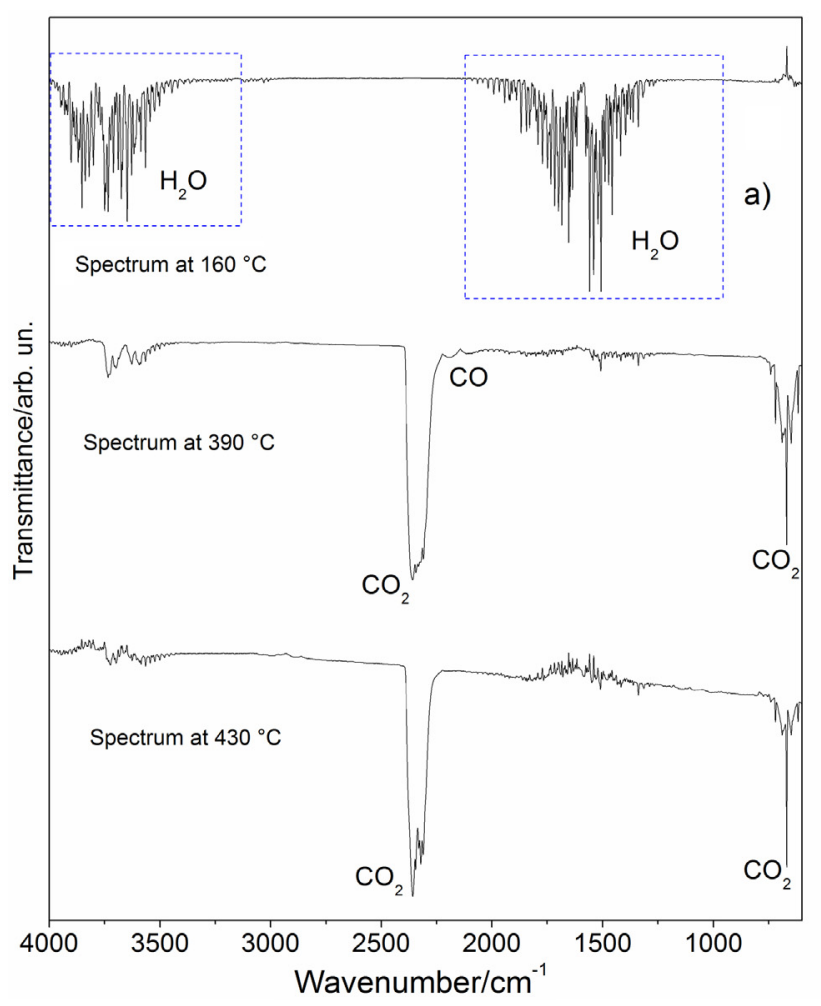

and $2128-1212 \mathrm{~cm}^{-1}$. In the following steps $\left(390^{\circ} \mathrm{C}\right.$ and $\left.425^{\circ} \mathrm{C}\right)$, the FTIR spectra show bands at $2356 \mathrm{~cm}^{-1}\left(v_{\mathrm{COO}}\right), 668 \mathrm{~cm}^{-1}\left(\delta_{\mathrm{COO}}\right.$, $2227-2037 \mathrm{~cm}^{-1}$ associated to the release of $\mathrm{CO}_{2}$ and $\mathrm{CO}[15,19]$. These gases are related to degradation and oxidation of ligand.

For the dynamic nitrogen atmosphere, the main gaseous products released during pyrolysis of complexes were $\mathrm{H}_{2} \mathrm{O}, \mathrm{CO}_{2}$, $\mathrm{CO}, \mathrm{NH}_{3}$ and Aniline, due to the presence of bands in FTIR spectra related to the release of the aforementioned gases. Bands in $3045 \mathrm{~cm}^{-1}\left(v_{\mathrm{C}-\mathrm{H}_{\mathrm{ar}}}\right), 1622 / 1510 \mathrm{~cm}^{-1}\left(v_{\mathrm{C}=\mathrm{C}_{\mathrm{ar}}}\right), 1273 \mathrm{~cm}^{-1}$ $\left(\nu_{\mathrm{C}-\mathrm{N}_{\mathrm{amine}}}\right), 1173-1085 \mathrm{~cm}^{-1}\left(\delta_{\mathrm{CCC}_{\mathrm{ar}}}\right), 875 \mathrm{~cm}^{-1}\left(\beta_{\mathrm{C}-\mathrm{H}_{\mathrm{ar}}}\right) 746\left(\delta_{\mathrm{CCN}}\right)$ $\mathrm{cm}^{-1}\left(\nu_{\mathrm{CO}}\right)$ and 987 and $930 \delta_{\mathrm{N}-\mathrm{H}} \mathrm{cm}^{-1}$ were assigned to the vibration modes groups presents of aniline and $\mathrm{NH}_{3}$ molecules $[15,19,20]$, see Fig. $3 b$.

\subsection{Vibrational spectroscopy}

Vibrational transitions of H-pABA, Na-pABA and compounds with $\mathrm{Eu}(\mathrm{III}), \mathrm{Gd}(\mathrm{III}), \mathrm{Tb}(\mathrm{III})$ and $\mathrm{Dy}(\mathrm{III})$ were studied in middle (MIR) and near (NIR) region, see Figs. 4 and 5, respectively.

The strong band at $1662 \mathrm{~cm}^{-1}$ in the MIR spectra of $\mathrm{H}-\mathrm{pABA}$ was attributed to $C=0$ stretching of free acid, bands in $3460 \mathrm{~cm}^{-1}$, $3364 \mathrm{~cm}^{-1}$ (harmonic band at $3381 \mathrm{~cm}^{-1}$ ) and a strong band in $1623 \mathrm{~cm}^{-1}$ were related to the vibrational modes of $-\mathrm{NH}_{2}$ group (stretching asymmetric, symmetric and bending, respectively)., C $\mathrm{N}$, and $\mathrm{C}-\mathrm{OH}$ stretches were characterized by the occurrence of the bands in MIR spectrum of $\mathrm{H}-\mathrm{pABA}$ in $1310 \mathrm{~cm}^{-1}(\mathrm{C}-\mathrm{N})$ and $1289 \mathrm{~cm}^{-1}$ (C - OH) [19-25].

For the sodium salt and synthetized complexes the MIR spectra do not showed the strong band in $1663 \mathrm{~cm}^{-1},(\nu \mathrm{C}=0)$. Nevertheless, intense bands found for the sodium salt at 1538 and $1392 \mathrm{~cm}^{-1}$ were attributed to the asymmetrical and symmetrical stretching frequencies of the carboxylate groups, respectively [15,23]. The asymmetrical and symmetrical stretching of carboxylate groups of europium, gadolinium, terbium and dysprosium complexes (see

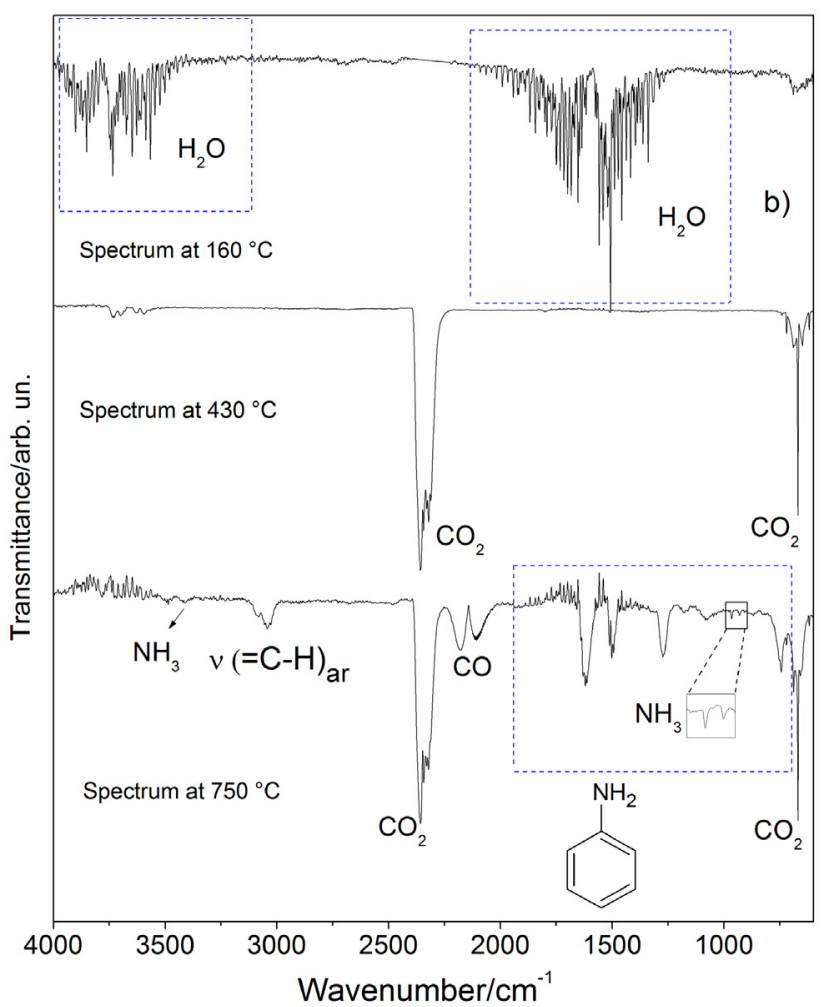

Fig. 3. MIR spectra from the gaseous products evolved during the thermal decomposition of terbium complex in dynamic dry air (a) and $\mathrm{N}_{2}$ (b) atmospheres. 
Table 2

Main vibrational data (MIR) for the $p$-aminobenzoic acid, their sodium salt and rare earth complexes.

\begin{tabular}{|c|c|c|c|c|c|c|}
\hline Assignment [13-15,20-25] & H-pABA & $\mathrm{Na}-\mathrm{pABA} \cdot 0 \cdot 5 \mathrm{H}_{2} \mathrm{O}$ & $\mathrm{Eu}(\mathrm{L})_{3} \cdot \mathrm{H}_{2} \mathrm{O}$ & $\mathrm{Gd}(\mathrm{L})_{3} \cdot \mathrm{H}_{2} \mathrm{O}$ & $\operatorname{Dy}(\mathrm{L})_{3} \cdot \mathrm{H}_{2} \mathrm{O}$ & $\mathrm{Tb}(\mathrm{L})_{3} \cdot \mathrm{H}_{2} \mathrm{O}$ \\
\hline vasNH $\mathrm{N}_{2}$ & $3460_{w}$ & $3377_{w}$ & 3457 vw & $3457 \mathrm{vw}$ & $3459_{\mathrm{vw}}$ & $3458_{\mathrm{vw}}$ \\
\hline$\nu \mathrm{SNH}_{2}$ & $3363_{w}$ & $3315_{w}$ & $3393 / 3373_{w}$ & $3392 / 3372_{w}$ & $3391 / 3373_{w}$ & $3391 / 3373_{w}$ \\
\hline$\nu \mathrm{OH}$ & $3000-3250_{w}$ & $3223_{w}$ & $3288_{\mathrm{w}}$ & $3290_{w}$ & $3290_{w}$ & $3300_{w}$ \\
\hline$\nu \mathrm{CH}$ & $3010-3050_{w}$ & $3045 / 3012_{w}$ & $3137_{w}$ & $3139_{w}$ & $3145_{w}$ & $3142_{w}$ \\
\hline $\mathrm{N}-\mathrm{H} \cdots \mathrm{O} / \mathrm{O}-\mathrm{H} \cdots \mathrm{N}$ & $2300-3000_{w}$ & & & & & \\
\hline$\nu \mathrm{C}=\mathrm{O}$ & $1663_{\mathrm{s}}$ & & & & & \\
\hline$\delta \mathrm{NH}_{2}$ & $1623_{\mathrm{m}}$ & $1598_{\mathrm{m}}$ & $1609_{\mathrm{m}}$ & $1609_{\mathrm{m}}$ & $1608_{\mathrm{m}}$ & $1609_{\mathrm{m}}$ \\
\hline$\nu \mathrm{C}=\mathrm{C}$ & $1598_{s}$ & & $1590_{\mathrm{m}}$ & $1591_{\mathrm{m}}$ & $1591_{\mathrm{m}}$ & $1591_{\mathrm{m}}$ \\
\hline$v C=C$ & $1574_{\mathrm{m}}$ & & & & & \\
\hline vasCOO- & & $1538_{\mathrm{vs}}$ & $1516 / 1504_{\mathrm{vs}}$ & $1518 / 1506_{\mathrm{vs}}$ & $1518 / 1506_{\mathrm{vs}}$ & $1518 / 1504_{\mathrm{vs}}$ \\
\hline$v \mathrm{C}=\mathrm{C}$ & $1522_{\mathrm{w}}$ & & & & & \\
\hline$\nu \mathrm{C}=\mathrm{C}$ & $1441_{\mathrm{m}}$ & & & & & \\
\hline$\delta \mathrm{OH}$ & $1421_{\mathrm{m}}$ & & & & & \\
\hline vsCOO${ }^{-}$ & & $1398_{\mathrm{vs}}$ & $1409 / 1396_{\mathrm{vs}}$ & $1410 / 1398_{\text {vs }}$ & $1409 / 1398$ & $1409 / 1398_{\mathrm{vs}}$ \\
\hline$\nu C-N$ & $1310_{s}$ & $1264_{\mathrm{m}}$ & $1293_{\mathrm{m}}$ & $1293_{\mathrm{m}}$ & $1293_{\mathrm{m}}$ & $1293_{\mathrm{m}}$ \\
\hline$\nu \mathrm{C}-\mathrm{OH}$ & $1289_{\mathrm{vs}}$ & & & & & \\
\hline$\delta_{\text {out }} \mathrm{NH}_{2}$ & $1072_{\mathrm{vw}}$ & $1084_{\mathrm{vw}}$ & $1087_{\mathrm{vw}}$ & $1088_{\mathrm{vw}}$ & $1087_{\mathrm{vw}}$ & $187_{\mathrm{vw}}$ \\
\hline$\delta \mathrm{CH}$ & & $1018_{\mathrm{vw}}$ & $1014_{w}$ & $1014_{\mathrm{w}}$ & $1014_{w}$ & $1014_{w}$ \\
\hline$\delta_{\text {out }} \mathrm{CH}$ & $842_{\mathrm{m}}$ & $845_{m}$ & $850_{\mathrm{m}}$ & $848_{m}$ & $847_{\mathrm{m}}$ & $847_{\mathrm{m}}$ \\
\hline$\delta_{\text {out }} \mathrm{CH}$ & $770_{\mathrm{vs}}$ & $782_{\mathrm{vs}}$ & $787_{\mathrm{vs}}$ & $787_{\mathrm{vs}}$ & $786_{\mathrm{vs}}$ & $787_{\mathrm{vs}}$ \\
\hline$\delta c-c-c$ & $699_{w}$ & $692_{\mathrm{m}}$ & $701_{s}$ & $701_{s}$ & $700_{s}$ & $700_{s}$ \\
\hline
\end{tabular}

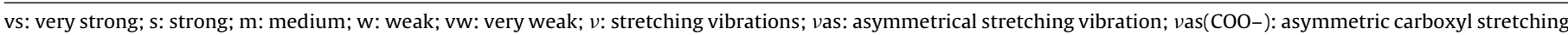
frequency; $\nu$ (COO-): symmetric carboxyl stretching frequency; $\delta$ : in plane bending vibration. $\delta$ out: out of plane bending vibration; L: $p$-aminobenzoate

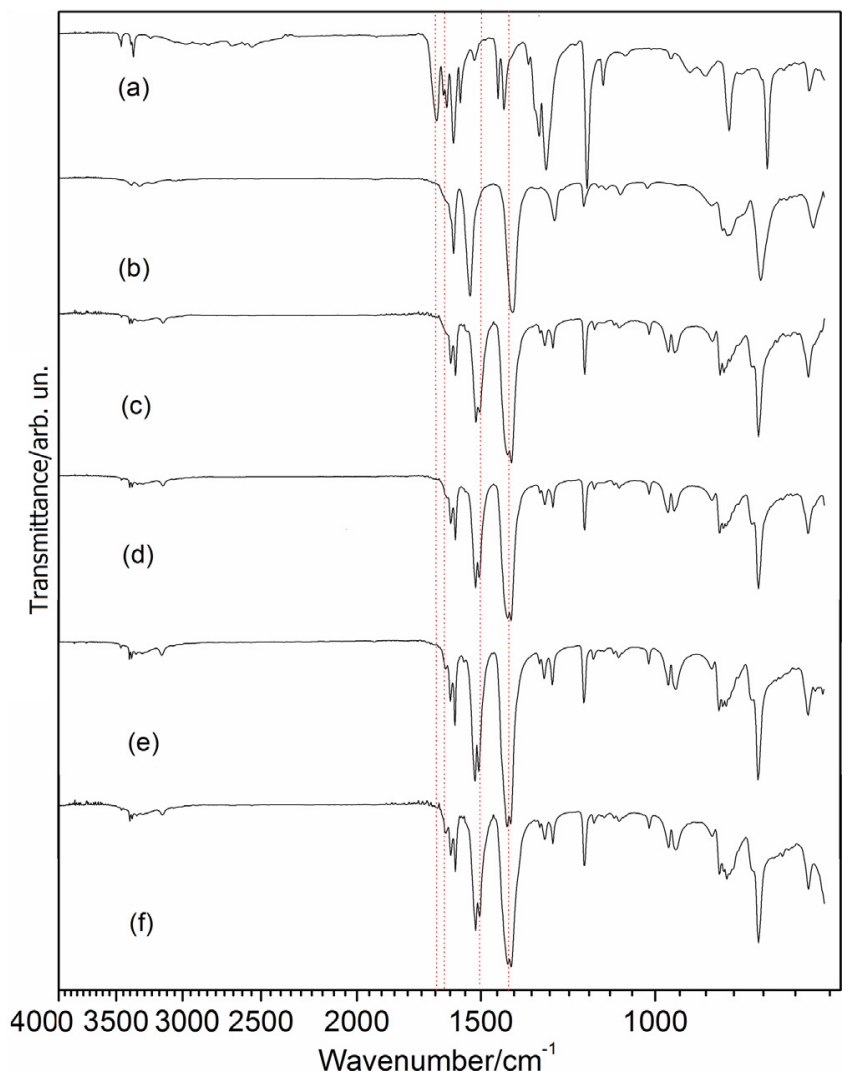

Fig. 4. MIR spectra of (a) $\mathrm{H}-\mathrm{pABA}$, (b) Na-pABA, (c) $\mathrm{Eu}(\mathrm{L})_{3} \cdot \mathrm{H}_{2} \mathrm{O}$, (d) $\mathrm{Gd}(\mathrm{L})_{3} \cdot \mathrm{H}_{2} \mathrm{O}$, (e) $\mathrm{Tb}(\mathrm{L})_{3} \cdot \mathrm{H}_{2} \mathrm{O}$ and (f) $\mathrm{Dy}(\mathrm{L})_{3} \cdot \mathrm{H}_{2} \mathrm{O}$.

Table 2) are located between 1504 and 1501 and $1393-1387 \mathrm{~cm}^{-1}$, respectively.

The difference between stretching frequencies $\left(\Delta v_{\mathrm{COO}} / v_{\mathrm{as}}-v_{\mathrm{s}}\right)$ for rare earth complexes ( $\Delta v=107$ to $120 \mathrm{~cm}^{-1}$ ) compared to the difference observed for the sodium salt $\left(\Delta \nu=146 \mathrm{~cm}^{-1}\right)$ indicate bidentate and/or bridged interaction of ligand with rare earth ions $[13,15,22,23]$.

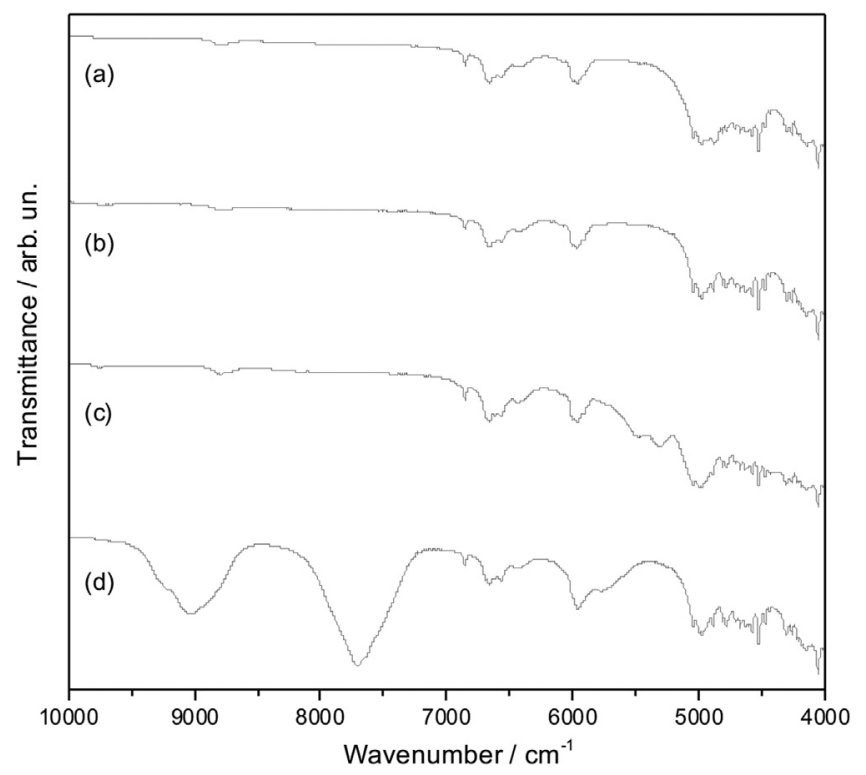

Fig. 5. NIR spectra of (a) europium, (b) gadolinium, (c) terbium and (d) dysprosium complexes.

The vibrational modes of the amino group of rare earth compounds and sodium salt were compared with H-pABA. It was observed a displacement in the wavenumber for the $\mathrm{C}-\mathrm{N}$ stretch in the spectrum of rare earth complexes, compared to the acid. These changes suggest the interaction of the $-\mathrm{NH}_{2}$ group with metal ion, which was in agreement with references [13-15].

The NIR spectra of H-pABA, their sodium salt and compounds with lighter trivalent rare earths (La-Sm) were studied in details in a previous work [15] and provided information about the combination and overtone bands of the compounds. Fig. 5 shows the NIR spectra of europium, gadolinium, terbium and dysprosium complexes and the assignments of the vibrational transitions of the complexes are in agreement with the previous related to the lanthanum complex [15]. Terbium and dysprosium complexes, also exhibited bands that were assigned to $f-f$ transitions (discussed below). Characteristics water bands appeared in the complexes spectra, in agreement with the TG-DTA results. Characteristics 


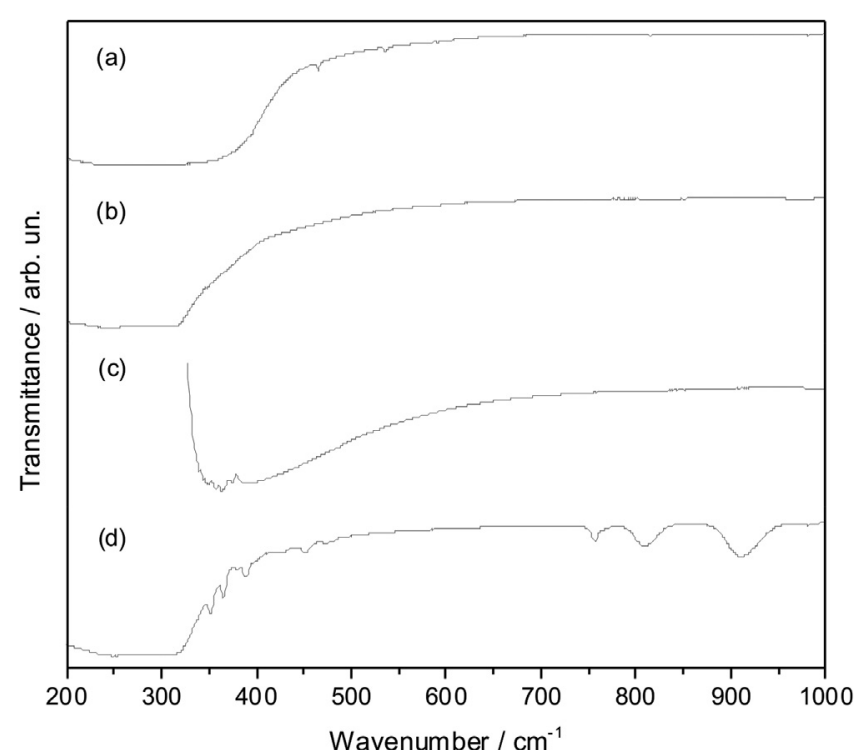

Fig. 6. DR spectra of (a) europium, (b) gadolinium, (c) terbium and (d) dysprosium complexes.

bands of carboxylic acid [15] do not appear in the complexes spectra, confirming the total deprotonation and the absence of acid contamination in the complexes.

\subsection{Electronic spectroscopy}

Electronic transitions of the complexes were studied in the ultraviolet, visible and near infrared regions.

The Diffuse Reflectance (DR) spectra (200-1000 nm) of the $\mathrm{RE}^{3+}$ complexes ( $\mathrm{Ln}=\mathrm{Eu}, \mathrm{Gd}, \mathrm{Tb}$ and Dy) are shown in Fig. 6. They exhibited a broad intra-ligand (IL) band in the UV and visible region $(200-430 \mathrm{~nm})$. In addition, the spectra of the europium and dysprosium complexes also showed the typical absorption bands due to $4 f-4 f$ transitions from the ground-states to the excited ones of the $\mathrm{Ln}^{3+}$ ions. In the case of the europium complex, in addition to transitions from the ground state, it was possible to observe the transition from the first excited level of the ground multiplet because this level have low energy values and can be populated at room temperature [26]. The europium spectra showed peaks of transitions from the ground state ${ }^{7} \mathrm{~F}_{0}$ and the ${ }^{7} \mathrm{~F}_{1}$ ground multiplets to excited states. The peaks at 464, 526, 536 and $591 \mathrm{~nm}$ are assigned to ${ }^{5} \mathrm{D}_{2} \longleftarrow{ }^{7} \mathrm{~F}_{0},{ }^{5} \mathrm{D}_{1} \longleftarrow{ }^{7} \mathrm{~F}_{0},{ }^{5} \mathrm{D}_{1} \longleftarrow{ }^{7} \mathrm{~F}_{1}$ and ${ }^{5} \mathrm{D}_{0} \longleftarrow{ }^{7} \mathrm{~F}_{1}$ transitions, respectively. ${ }^{5} \mathrm{D}_{2} \longleftarrow{ }^{7} \mathrm{~F}_{0}$ and ${ }^{5} \mathrm{D}_{1} \longleftarrow{ }^{7} \mathrm{~F}_{1}$ transitions have induced magnetic dipole character, while, ${ }^{5} \mathrm{D}_{1} \longleftarrow{ }^{7} \mathrm{~F}_{0}$ and ${ }^{5} \mathrm{D}_{0} \longleftarrow{ }^{7} \mathrm{~F}_{1}$ have magnetic dipole character [27]. The apparent low intensity absorption in the $\sim 200-350 \mathrm{~nm}$ region of terbium complex is an effect of the equipment registration of the intense visible luminescence excited in this region [13].

Dysprosium complex spectra shows peaks corresponding to the transitions from the ${ }^{6} \mathrm{H}_{15 / 2}$ ground state to the excited states. The peaks located at 352, 365, 378, $389,427,452,474,757,809$ and $910 \mathrm{~nm}$ are assigned to ${ }^{6} \mathrm{P}_{7 / 2} \longleftarrow{ }^{6} \mathrm{H}_{15 / 2},{ }^{6} \mathrm{P}_{5 / 2} \longleftarrow{ }^{6} \mathrm{H}_{15 / 2},{ }^{4} \mathrm{I}_{13 / 2} \longleftarrow{ }^{6} \mathrm{H}_{15 / 2},{ }^{4} \mathrm{~F}_{7 / 2} \longleftarrow{ }^{6} \mathrm{H}_{15 / 2}$, ${ }^{4} \mathrm{G}_{11 / 2} \longleftarrow{ }^{6} \mathrm{H}_{15 / 2},{ }^{4} \mathrm{I}_{15 / 2} \longleftarrow{ }^{6} \mathrm{H}_{15 / 2},{ }^{4} \mathrm{~F}_{9 / 2} \longleftarrow{ }^{6} \mathrm{H}_{15 / 2},{ }^{6} \mathrm{~F}_{3 / 2} \longleftarrow{ }^{6} \mathrm{H}_{15 / 2}$, ${ }^{6} \mathrm{~F}_{5 / 2} \longleftarrow{ }^{6} \mathrm{H}_{15 / 2}$ and ${ }^{6} \mathrm{~F}_{7 / 2} \longleftarrow{ }^{6} \mathrm{H}_{15 / 2}$ transitions, respectively.

In the NIR spectra (Fig. 5), terbium and dysprosium complexes shown characteristics $4 f-4 f$ transitions. Terbium complex NIR spectra shows two peaks located at $5500 \mathrm{~cm}^{-1}(1818 \mathrm{~nm})$ and $5313 \mathrm{~cm}^{-1}(1882 \mathrm{~nm})$ assigned to the ${ }^{7} \mathrm{~F}_{0} \longleftarrow{ }^{7} \mathrm{~F}_{6}$ and ${ }^{7} \mathrm{~F}_{1} \longleftarrow{ }^{7} \mathrm{~F}_{6}$ transition, respectively. Dysprosium complex NIR spectra shows peaks located at 9062 and $7704 \mathrm{~cm}^{-1}(1103$ and $1298 \mathrm{~nm})$, assigned

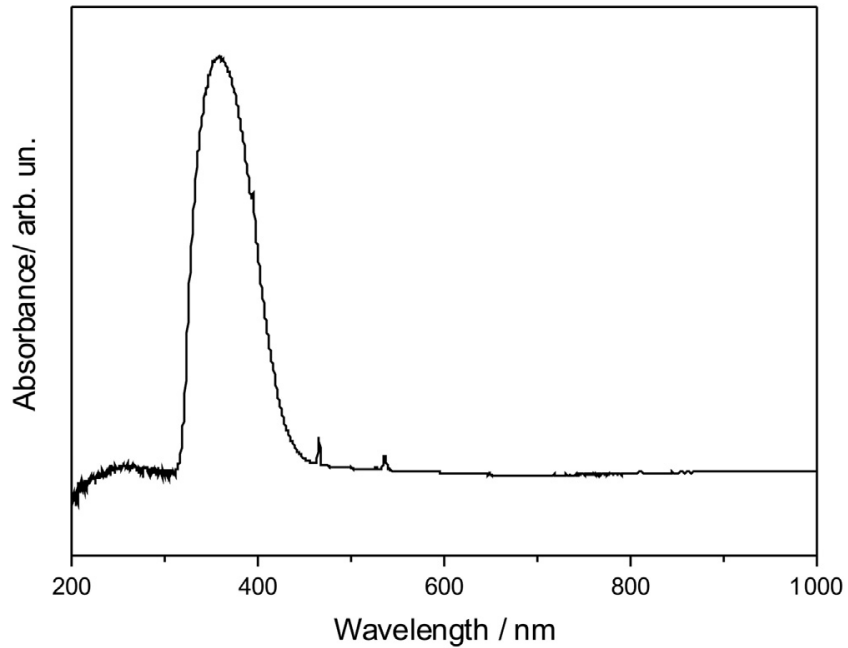

Fig. 7. DR spectra (in absorbance) of the arithmetic difference between the europium(III) and gadolinium(III) complexes diffuse reflectance spectra showing the LMCT band.

to the ${ }^{6} \mathrm{~F}_{9 / 2}+{ }^{6} \mathrm{H}_{7 / 2} \longleftarrow{ }^{6} \mathrm{H}_{15 / 2}$ and ${ }^{6} \mathrm{~F}_{11 / 2}+{ }^{6} \mathrm{H}_{9 / 2} \longleftarrow{ }^{6} \mathrm{H}_{15 / 2}$, respectively. The transition ${ }^{6} \mathrm{~F}_{11 / 2} \longleftarrow{ }^{6} \mathrm{H}_{15 / 2}$ is hypersensitive.

To study the nature of the europium complex transition at ultraviolet and visible region, the arithmetic difference between the diffuse reflectance spectra in the solid state of the europium(III) and gadolinium(III) complexes was done (Fig. 7) [28]. The arithmetic difference reveals the presence of a ligand-to-metal $\left(\mathrm{O}^{2-} \rightarrow \mathrm{Eu}^{3+}\right)$ charge transfer (LMCT) in the range $305-470 \mathrm{~nm}$ (32787-21277 $\left.\mathrm{cm}^{-1}\right)$. For europium complex, the presence of LMCT state in the $22000-24000 \mathrm{~cm}^{-1}$ region promotes a strong quenching in the luminescence [29], in agreement with the low intensity of the europium $p$-aminobenzoate complex related in several studies $[30,31]$.

\section{Conclusions}

From the TG, complexometry and elemental analysis data, a general formula could be stablished for europium, gadolinium, terbium and dysprosium complexes in the solid-state. For the all complexes synthesized, the dehydration occurred in a single step with release of $1 \mathrm{H}_{2} \mathrm{O}$.

The TG-DTA curves provided previously unreported information regarding the thermal stability, thermal decomposition, and physical characteristics of these complexes in dynamic dry air and nitrogen atmosphere. The DSC curves in nitrogen atmosphere provided information on the phase transition enthalpy for the complexes.

The gaseous products released during thermal decomposition and pyrolysis of the complexes were reported using EGA analysis, the gases released were $\mathrm{CO}, \mathrm{CO}_{2}$ and $\mathrm{NH}_{3}$ in air atmosphere and $\mathrm{CO}$, $\mathrm{CO}_{2}, \mathrm{NH}_{3}$ and Aniline in nitrogen atmosphere.

The X-ray powder patterns showed that all the compounds have a crystalline structure, with evidence of the formation of isomorphous complexes.

The MIR spectroscopic data suggest the assignment of the vibrational modes for the complexes and which both amine and carboxyl groups acts a coordination site, while the NIR spectroscopic data confirms the presence of water in the complexes structure and the absence of acid contamination.

Electronic transitions of the complexes were studied in UV, visible and near infrared regions. Characteristics $4 f-4 f$ transitions are seen in visible region for europium and dysprosium complexes, while characteristics $4 f-4 f$ transitions appear in terbium 
and dysprosium complexes. The arithmetic difference between the diffuse reflectance spectra in the solid state of the europium(III) and gadolinium(III) complexes reveals the presence of a ligandto-metal $\left(\mathrm{O}^{2-} \rightarrow \mathrm{Eu}^{3+}\right)$ charge transfer (LMCT) in the $305-470 \mathrm{~nm}$ range (32787-21277 $\left.\mathrm{cm}^{-1}\right)$, which acts as an efficient quenching route for the luminescence of the europium complex.

\section{Acknowledgments}

The authors thanks FAPESP (Proc. 2013/09022-7), CNPq, and CAPES foundations (Brazil) for financial support.

\section{Appendix A. Supplementary data}

Supplementary data associated with this article can be found, in the online version, at http://dx.doi.org/10.1016/j.jaap.2016.08.006.

\section{References}

[1] N.M. Hosny, E.S.A. El Morsy, Y.E. Sherif, Synthesis spectral, optical and anti-inflammatory activity of complexes derived form 2-aminobenzohydrazide with some rare earth, J. Rare Earths 33 (2015) $758-764$.

[2] X. Sun, X. Jin, W. Pan, J. Wang, Syntheses of new rare earth complexes with carboxymethylated polysaccharides and evaluation of their in vitro antifungal activities, Carbohydr. Polym. 133 (2014) 194-199.

[3] Y.-N. Liu, S. Shi, W.-J. Mei, C.-P. Tan, L.-M. Chen, J. Liu, W.-J. Zheng, J. Liang-Nian, In vitro and in vivo investigations on the antiviral activity of a series of mixed-valence rare borotungstate heteropoly blues, Eur. J. Med. Chem. 43 (2008) 1963-1970.

[4] X. Zhu, Y. Wang, Y. Yao, B. Wu, Q. Shen, Synthesis, structure and catalytic behavior of ytterbium complexes bearing a phenoxy(quinolinyl)amide ligand, J. Rare Earths 30 (2012) 909-915.

[5] N. Sun, X. Zhao, Y. Yang, L. Li, A. Zhang, H. Jia, X. Liu, Synthesis and luminescent properties of terbium complex containing 4-benzoylbenzoic acid for application in NUV-based LED, J. Rare Earths 34 (2016) 130-136.

[6] H. Tan, C. Ma, L. Chen, F. Xu, S. Chen, L. Wang, Nanoscaled lanthanide/nucleotide coordination polymer for detection of an anthrax biomarker, Sens. Actuators B 190 (2014) 621-626.

[7] J. Shen, L. Zhao, G. Han, Lanthanide-doped up-converting luminescente nanoparticle platforms for optical imaging-guided drug delivery and therapy, Adv. Drug Deliv. Rev. 65 (2013) 744-755.

[8] D.A. Gálico, M.G. Lahoud, M.R. Davolos, R.C.C. Frem, T.F.C. Fraga-Silva, J. Venturini, G. Bannach, Spectroscopic: luminescence and in vitro biological studies of solid ketoprofen of heavier trivalent lanthanides and yttrium (III), J. Inorg. Biochem. 140 (2014) 160-166.

[9] A. Aragón-Muriel, M. Camprubi-Robles, E. González-Rey, A. Salinas-Castillo, A. Rodrígues-Diéguez, S. Gómez-Ruiz, D. Polo-Cerón, Dual investigation of lanthanide complex with cinnamate and phenylacetate ligands: study of the cytotoxic properties and the catalytic oxidation of styrene, Polyhedron 80 (2014) 117-128.

[10] British Pharmacopoeia 2009, vol I and II, The Stationary Office, London, 2009

[11] R.M.E. Richards, D.K.L. Xing, The effect of $p$-aminobenzoic acid on the uptake of thymine and uracil by Escherichia coli, Int. J. Pharm. 116 (1995) 217-221.

[12] S.I. Akberova, New biological properties of $p$-aminobenzoic acid, Biol. Bull. 29 (2002) 390-392.
[13] T. Tsaryuk, A. Vologzhamina, K. Zhuravlev, V. Kudryashova, R. Szostak, V. Zolin, Structures and manifestation of ortho- meta-, and para- $\mathrm{NH}_{2}$-substitution in the optical spectra of europium and terbium aminobenzoates, J. Photochem. Photobiol. A 285 (2014) 52-61.

[14] H.-L. Sun, C.-H. Ye, X.-Y. Wang, J.-R. Li, S. Gao, K.-B. Yu, Lanthanide contraction and $\mathrm{pH}$ value controlled structural change in a series of rare earth complexes with p-aminobenzoic acid, J. Mol. Struct. 702 (2004) 77-83.

[15] J.A. Teixeira, W.D.G. Nunes, T.A.D. Colman, A.L.C.S. Nascimento, F.J. Caires, F.X. Campos, D.A. Gálico, M. Ionashiro, Thermal and spectroscopic study to investigate $p$-aminobenzoic acid: sodium $p$-aminobenzoate and its compounds with some lighter trivalent lanthanides, Thermochim. Acta 624 (2016) 59-68.

[16] D.J.C. Gomes, F.J. Caires, R.C. Silva, O. Treu-Filho, M. Ionashiro, Synthesis characterization, thermal and spectroscopic studies of solid glycolate of light trivalent lanthanides, except promethium, Thermochim. Acta 587 (2014) 33-41.

[17] H.A. Flaschka, EDTA Titrations and Introduction to Theory and Practice, 2nd ed., Press Oxford, Pergamon, 1964.

[18] M. Ionashiro, C.A.F. Gramer, J. Zuanon Netto, Titulação complexometrica de lantanideos e ítrio, Ecl. Quím. 8 (1983) 29-32.

[19] M. Mukherjee, B. Bandyopadhyay, P. Biswas, T. Chakraborty, Amine inversion effects on the IR spectra of aniline in the gas phase and cold inert gas matrixes, Indian J. Phys. 86 (2012) 201-208.

[20] R.M. Silverstein, F.X. Webster, Spectrometric Identification of Organic Compounds, 6th ed., Wiley, New York, 1998.

[21] K. Nakamoto, Infrared and Raman Spectra of Inorganic and Coordination Compounds, Part B. 5th ed., Wiley, Ney York, 997.

[22] G.B. Deacon, R.J. Phillips, Relationships between the carbon?oxygen stretching frequencies of carboxylato complexes and the type of carboxylate coordination, Coord. Chem. Rev. 33 (1980) 227-250.

[23] M. Samsonowicz, T. Hrynaszkiewicz, R. Swislocka, E. Regulska, W. Lewandowski, Experimental and theoretical I.R. raman, NMR, spectra of 2-3and 4-aminobenzoic acids, J. Mol. Struct. 744-747 (2005) 345-352.

[24] R. Swislocka, M. Samsonowicz, E. Regulska, W. Lewandowski, Molecular Structure of 4-aminobenzoic acid salts with alkali metals, J. Mol. Struct. 792-793 (2006) 227-238.

[25] G. Versanyi, Assignments for Vibrational Spectra of 700 Benzene Derivatives, Akademiai Kiado, Budapest Hungary, 1973.

[26] V.S. Sastri, J.C.G. Bünzli, V.R. Rao, G.V.S. Rayudu, J.R. Perumareddi, Modern Aspects of Rare Earths and Their Complexes, Elsevier, Amsterdam, 2003.

[27] K. Binnemans, Interpretation of europium(III) spectra, Coord. Chem. Rev. 295 (2015) 1-45.

[28] J.A. Fernandes, R.A.S. Ferreira, M. Pillinger, L.D. Carlos, I.S. Goncalves, P.J.A Ribeiro-Claro, Spectroscopic studies of Europium(III) and Gadolinium(III) tris- $\beta$-diketonate complexes with diazabutadiene ligands, Eur. J. Inorg. Chem. 19 (2004) 3913-3919.

[29] J.-C.G. Bünzli, On the design of highly luminescent lanthanide complexes, Coord. Chem. Rev. 293-294 (2015) 19-47.

[30] T. Fiedler, M. Hilder, P.C. Junk, U.H. Kynast, M.M. Lezhnina, M. Warzala, Synthesis structural and spectroscopic studies on the lanthanoid p-aminobenzoates and derived optically functional polyurethane composites, Eur. J. Inorg. Chem. 2 (2007) 291-301.

[31] S. Panadero, A. Gómez-Hens, D. Pérez-Bendito, Use of time-resolved lanthanide-sensitized luminescence for the kinetic determination of p-aminobenzoic acid, Talanta 45 (1998) 829-834. 